\title{
Pharmacognostic and Preliminary Phytochemical Evaluation of Leaf of Syzygium Cumini (L.) Skeels
}

\author{
Research Article
}

\section{Shyam Baboo Prasad1*, Arun M Gurav², Goli P Prasad³ Anupam K Mangal ${ }^{4}$, Srikanth $\mathrm{N}^{5}$}

\section{Research Officer Pharmacognosy, 2. Assistant Director Incharge,} Regional Ayurveda Research Institute, Kothrud, Pune.

3. Assistant Director Incharge, National Centre of Indian Medical Heritage, Hyderabad.

4. Assistant Director Pharmacognosy, Central Council for Research in Ayurvedic Sciences, New Delhi.

5. Director General I/c, Central Council for Research in Ayurvedic Sciences, New Delhi (India).

\begin{abstract}
Syzygium cumini (L.) Skeels (Family: Myricaceae) commonly known as Jamun is a widely used medicinal plant in Ayurveda. In spite of its numerous medicinal attributes, no published work is available on pharmacognostic characterization, physicochemical analysis of its leaves. The measures taken for pharmacognostic characterization were macroscopy, microscopy, powder microscopy, physicochemical evaluation, fluorescence analysis, and preliminary phytochemical screening. The microscopic evaluation showed useful characters for the recognition of leaf of Syzygium cumini (L.) Skeels . Transverse section, showed presence of single layer of wavy epidermal cells with striated cuticle single layer Palisade beneath upper epidermis in lamina region (contains compact elongated cells), Spheraphide in lamina region, collenchyma below the upper epidermis and above the lower epidermis in midrib region, Xylem and phloem in center, Sclerenchyma in between vascular bundle and collenchyma in midrib region. Wavy epidermal cell in the upper epidermis, anisocytic stomata in the lower epidermis, Bordered pitted reticulate vessels, Calcium oxalate crystal sheath in the lamina, fragment of fibers and Spiral vessels were observed in powder microscopy. Physicochemical studies showed total ash (3.1\%), acid insoluble ash $(0.7 \%)$, alcohol soluble extractive values $(10.96 \%)$, and water-soluble extractive values $(12.32 \%)$. Phytochemical analysis revealed the presence of sugar, lipid, Glycoside, saponins, phenols, flavonoids, tannins, tri-terpenoids and steroids. The study forms the first report on pharmacognostic characters and a physicochemical parameter which could be useful for identification and authentication of the plant.
\end{abstract}

Key Words: Fluorescence, Jamun leaf, Microscopy, Syzygium cumini, Standardisation.

\section{Introduction}

Syzygium cumini (L.) SKEELS is also known as Calyptranthes jambolana MOON., Eugenia jambolana LAM., Syzygium jambolana DC., and Syzygium jambolanum DC. S. cumini commonly known as jambolan, Java plum, black plum or Jamun, is an evergreen tropical tree in the flowering plant family Myrtaceae. Within India, it is said to be found throughout, except in desert areas, either in wild or cultivated forms. The evergreen Jamun plant is originally from Indonesia and India $(1,2)$. Indian mythology describes the Indian subcontinent as Jambudweep, because of a majority of Jamun trees. Traditionally the whole plant is used for its

* Corresponding Author:

Shyam Baboo Prasad

Research Officer Pharmacognosy,

Regional Ayurveda Research Institute,

Kothrud,

Pune. India

Email Id: b.shyam2@gmail.com multipurpose benefits. Despite its ethnopharmacological uses, presently leaves is proven to have many therapeutic valuable uses because of the presence of many phyto-constituents (3-4). (Table 1)

The leaves are used to treat leucorrhoea, stomach-ache, fever, dermopathy, constipation, inhibit blood discharges in the faeces and reduce radiationinduced DNA damage (4).

Pharmacognostic and Physicochemical evaluation of medicinal plants is essential in order to identification, detection of adulteration and assessment of quality which is directly linked with the efficacy. The quality assessment of medicinal plants is of paramount importance in order to justify their acceptability in the modern era. One of the major problems faced by the herbal industry is the unavailability of rigid quality control profiles for herbal materials (5). The literature search revealed that there is not a single report on the pharmacognostic evaluation of leaf of S. cumini . Therefore detailed study on pharmacognostic standardization was undertaken as per the standards/ guidelines of API and WHO for medicinal plants. 


\section{Materials and Methods}

\section{Plant material}

Leaves of Syzygium cumini (L.) SKEELS was collected from the plant growing on the campus of Regional Ayurveda Institute for Fundamental Research, Pune, Maharashtra, India.

Identification and authentication of plant material

Plant material was identified and authenticated with the help of the Flora (6).

Plant material was also compared with the herbarium specimen available in the herbarium section of the Institute. Herbarium of the plant specimen was prepared and deposited in the herbarium section of the RAIFR, Pune with voucher specimen number 14424.

\section{Powder preparation}

Shade dried leaves were made into powder using grinding mill; passed through \#60 sieve and kept in an airtight container for further analysis (7).

\section{Macroscopic characterization}

Macroscopic characters of leaf were studied $(8,9)$.

\section{Microscopic characterization}

It involved only powder microscopy, performed by preparing the dried materials, coarsely powdered. Photomicrograph of powder study was captured using Deno Capture 2.0 version 142D, the versatile digital microscope.

Freehand sections (T.S.) of a leaf were taken and stained with Phloroglucinol, followed by Hydrochloric acid. Microphotographs were snapped with the help of Deno Capture 2.0 version 142D, the versatile digital microscope $(8,9)$. Image were captured at $4 \mathrm{X}$ and $10 \mathrm{X}$.

\section{Preliminary phytochemical screening}

Alcoholic and aqueous extract of $S$. cumini were prepared by cold maceration method. Coarsely powdered air-dried material $5 \mathrm{~g}$ was accurately weighed and placed in a glass stoppered conical flask. It was macerated with $100 \mathrm{ml}$ of the solvent specified for $6 \mathrm{hr}$, shaken frequently and then allowed to stand for 18 hr. Filtered rapidly taking care not to lose any solvent, filtrate was transferred to a tared flat bottomed dish and evaporated to dryness on a digital water bath at $60^{\circ} \mathrm{C}$. Both the extracts were subjected to phytochemical screening for qualitative analysis for the presence and absence of secondary metabolites $(8,9)$.

\section{Histochemistry, behaviour of powder and fluorescence analysis}

Dried leaves powder was used for the analysis of Histochemical, behaviour of powder, fluorescence analysis (8).

\section{Determination of physicochemical parameters}

Physicochemical parameters namely, loss on drying, ash value, acid insoluble ash, water-soluble extractive, alcohol soluble extractive were performed as per the standard protocol of Ayurvedic pharmacopeia of India (10).

\section{Results and Discussion}

\section{Macroscopic and organoleptic evaluation}

The image of the leaf of $S$. cumini is shown in figure 1. The detail of macroscopic characters and organoleptic characters are shown in figure 1. The description of macroscopic studies is as follows.

- Shape: Oblong-oval or elliptic

- Size : leaf is $5-18 \mathrm{~cm}$ long and 2.5 to $8 \mathrm{~cm}$ wide, stalk 0.7 $2.2 \mathrm{~cm}$ long

- Apex: Blunt or tapering to a point.

- Margin: Entire

- Base: Slightly unequal

- Colour: Leaf: Upper surface and the lower surface of the fresh leaf is dark green and light-green respectively. The upper surface and the lower surface of the dried leaf are brownish green and light brown respectively. ; Stalk Slender and light yellow in fresh while brown in dried leaves. , $0.7-2.2 \mathrm{~cm}$ long

- Odour: Turpentine like.

- Taste: Slightly astringent.

- Touch: Leather like.

\section{Microscopic studies}

The upper epidermis shows the presence of a single layer of wavy epidermal cells with striated cuticle. Palisade is made up of a single layer beneath upper epidermis in the lamina region and contains compact elongated cells. Spongy parenchyma is 5 to 8 layered. Spheraphide is distinctly visible in the lamina region between palisade cells and spongy parenchyma cells. Midrib shows the presence of collenchyma below the upper epidermis and above the lower epidermis. Vascular bundle (Xylem and phloem) are present in the center. Sclerenchyma is present in between the vascular bundle and collenchyma in the midrib region.

Powder under a microscope showed different anatomical characters are shown in figure 3. Details of the characters recorded are given below the figure 3 . Preliminary phytochemical screening of extract:

Preliminary phytochemical screening depicts the presence phytoconstituents as depicted in Table: 2 .

\section{Histochemical and fluorescence analysis}

Powder drug was analyzed for 3 separate batches for histochemical tests for the detection of lignin, aleurone grains, oils, mucilage, and crystals. The analysis result is depicted in (Table- 3).

Powder drug was treated with different chemical reagents and observed in daylight and ultra-violet light and inferences were recorded in Table- 4. Drug color changed after reacting with chemical and observed under 254 and $366 \mathrm{~nm}$ for 3 different batches would be characteristics for a particular drug and would be beneficial to identify the leaf powder of S. cumini.

\section{Determination of physicochemical parameters}

Results obtained from physicochemical contents such as loss on drying, total ash, acid insoluble ash, water, and alcohol soluble extracts are depicted in Table 5.

Macroscopic assessment of medicinal plants plays a critical role in the identification and detection of adulterant (9). In some cases quality of medicinal plants cannot be assessed on the basis of morphology only. The microscopic 
(transverse section) evaluation allows a more detail examination of a medicinal plant and it can be used to identify the organized drugs by their known histological character. Powder microscopy imparts a crucial role in a similar way as T.S. of leaf (11). Pharmacological action of the drug is due to either a constituent or due to blends of constituent.5 Phytochemical screening and fluorescence analysis help in evaluating for presence and absence of phytoconstituents $(9,10)$. Standardization of medicinal plants is a complex process so different physicochemical parameters impart an important role in standardization. The physicochemical parameter can be used as a standard to ensure the quality of crude drug (10). The Ash value of leaf shows the presence of inorganic content. The lower value of the acid-insoluble ash suggests the greater physiological availability of the drug. Extractive value gives information about the availability of soluble phytoconstituents in a particular solvent. The low value of moisture content does not promote microbial contamination as the general requirement of moisture content in the crude drug is not more than $14 \%(\mathrm{~W} / \mathrm{W})$.

\section{Conclusion}

The result of present study would serve as a source of valuable information for standardization and quality control of leaf of Syzygium cumini (L.) SKEELS.

\section{Table1 - Phytoconstituents of Leaf}

\section{Category Phytoconstituents}

Acid Betulinic acid, crategolic acid, ellagic acids

Alkyl alcohol Octacosanol, n-triacontanol, n-dotricontanol

Essential oils Pinocarveol, a-terpeneol, myrtenol, eucarvone, muurolol, a- myrtenal, cineole, geranyl acetone, acadinol and pinocarvone, eugeneol

Flavanol Quercetin, myricetin, myricitrin, myrecetin 3-0-D glycosides glucaronopyranoside, $3-0-\beta$ D glucuronopyranoside,: mearsetin 2-0-(4"-0-acetyl)a-L rhamnopyranoside, and myricetin 4"-0acetyl"-2-0-gallate.

Hydrocarbon n-hepatcosane, n-nonacosane, n-hentriacontane, eicosane, octadecane

Phytosterols ß-sitosterol

Polyphenol gallic acid, methylgallate, kaempferol, ellagic acid, ellagitannin, nilocitin

Sugar mycaminose

Table 2 - Preliminary Phytochemical screening

S.No. Phytoconstituents Aqueous extract Alcoholic extract

\begin{tabular}{|l|l|l|l|}
\hline 1 & Sugar & + & + \\
\hline 2 & Protein & - & - \\
\hline 3 & Lipid & + & + \\
\hline 4 & Alkaloids & - & - \\
\hline 5 & Glycoside & + & + \\
\hline 6 & Phenolics & ++ & ++ \\
\hline 7 & Flavonoids & ++ & ++ \\
\hline 8 & Tannins & ++ & ++ \\
\hline 9 & Saponin & - & - \\
\hline 10 & Volatile oils & + & + \\
\hline 11 & Triterpenoids & + & + \\
\hline 12 & Steroids & + & + \\
\hline
\end{tabular}

+ Present, - absent
Table 3 - Histo-chemical analysis

\begin{tabular}{|c|c|c|c|c|}
\hline $\begin{array}{l}\text { Sr. } \\
\text { No. }\end{array}$ & Test & Chemical & Observation & Result \\
\hline 1 & Lignified cell & $\begin{array}{l}\text { Phloroglucinol } \\
+\mathrm{HCl}\end{array}$ & $\begin{array}{l}\text { Pink to cherry } \\
\text { red colour }\end{array}$ & + \\
\hline 2 & Cuticular cell & Sudan red -III & $\begin{array}{l}\text { Orange red or } \\
\text { red }\end{array}$ & + \\
\hline 3 & $\begin{array}{l}\text { Aleurone } \\
\text { grains }\end{array}$ & Iodine & $\begin{array}{l}\text { Yellowish } \\
\text { brown to } \\
\text { brown }\end{array}$ & - \\
\hline 4 & $\begin{array}{l}\text { Fats and } \\
\text { volatile oils }\end{array}$ & Sudan red- III & $\begin{array}{l}\text { Orange red to } \\
\text { red }\end{array}$ & + \\
\hline 5 & $\begin{array}{l}\text { Mucilage } \\
\text { fatty oils }\end{array}$ & Ruthenium red & Pink & - \\
\hline 6 & Starch & Iodine & $\begin{array}{l}\text { Blue or } \\
\text { reddish blue }\end{array}$ & + \\
\hline 7 & $\begin{array}{l}\text { Calcium } \\
\text { oxalate } \\
\text { crystals }\end{array}$ & $\begin{array}{l}\text { Hydrochloric } \\
\text { acid }\end{array}$ & Dissolved & + \\
\hline 8 & $\begin{array}{l}\text { Calcium } \\
\text { carbonate } \\
\text { crystals }\end{array}$ & $\begin{array}{l}\text { Hydrochloric } \\
\text { acid }\end{array}$ & $\begin{array}{l}\text { Dissolved } \\
\text { with } \\
\text { effervescence }\end{array}$ & - \\
\hline
\end{tabular}

Table 4- Fluorescence analysis

\begin{tabular}{|c|c|c|c|c|}
\hline $\begin{array}{l}\text { Sr. } \\
\text { No. }\end{array}$ & Test & Day light & $254 \mathrm{~nm}$ & $366 \mathrm{~nm}$ \\
\hline 1 & $\begin{array}{l}\text { Powder as } \\
\text { such }\end{array}$ & Greenish light & $\begin{array}{l}\text { Herbage } \\
\text { green }\end{array}$ & $\begin{array}{l}\text { Fuscous } \\
\text { black }\end{array}$ \\
\hline 2 & $\begin{array}{l}\text { Powder }+ \\
\mathrm{H}_{2} \mathrm{O}\end{array}$ & $\begin{array}{l}\text { Slightly light } \\
\text { citrine }\end{array}$ & $\begin{array}{l}\text { Umber } \\
\text { light }\end{array}$ & $\begin{array}{l}\text { Greyish } \\
\text { blue }\end{array}$ \\
\hline 3 & $\begin{array}{l}\text { Powder }+ \\
\mathrm{HCl}\end{array}$ & $\begin{array}{l}\text { Olivaceous } \\
\text { buff }\end{array}$ & Flax blue & $\begin{array}{l}\text { Glaucous } \\
\text { sky blue }\end{array}$ \\
\hline 4 & $\begin{array}{l}\text { Powder }+ \\
\mathrm{HNO}_{3}\end{array}$ & orange & Bay & $\begin{array}{l}\text { Blood } \\
\text { colour }\end{array}$ \\
\hline 5 & $\begin{array}{l}\text { Powder }+ \\
\mathrm{H}_{2} \mathrm{SO}_{4}\end{array}$ & Apricot & Bay & $\begin{array}{l}\text { Blood } \\
\text { colour }\end{array}$ \\
\hline 6 & $\begin{array}{l}\text { Powder }+ \\
\text { Glacial } \\
\text { Acetic acid }\end{array}$ & Citrine & $\begin{array}{l}\text { Livid } \\
\text { vanaceous }\end{array}$ & $\begin{array}{l}\text { Pale } \\
\text { Vinaceous }\end{array}$ \\
\hline 7 & $\begin{array}{l}\text { Powder + } \\
\text { Conc.Hcl } \\
\text { and } \\
\text { water(1:1) }\end{array}$ & $\begin{array}{l}\text { Olivaceous } \\
\text { buff }\end{array}$ & Fawn & Lavender \\
\hline 8 & $\begin{array}{l}\text { Powder } \\
+50 \% \mathrm{HNO}_{3}\end{array}$ & Cinnamon & $\begin{array}{l}\text { Dark } \\
\text { vinaceous }\end{array}$ & $\begin{array}{l}\text { Vinaceous } \\
\text { buff }\end{array}$ \\
\hline 9 & $\begin{array}{l}\text { Powder } \\
+50 \% \\
\mathrm{H}_{2} \mathrm{SO}_{4}\end{array}$ & Citrine & Chestnut & $\begin{array}{l}\text { Dark } \\
\text { purple }\end{array}$ \\
\hline 10 & $\begin{array}{l}\text { Powder } \\
+50 \% \mathrm{G} . \\
\text { Acetic acid }\end{array}$ & Citrine & Dark violet & Flex blue \\
\hline 11 & $\begin{array}{l}\text { Powder }+ \\
1 \mathrm{~N} \mathrm{NaOH}\end{array}$ & Ochereous & Chestnut & $\begin{array}{l}\text { Dark } \\
\text { purple }\end{array}$ \\
\hline 12 & $\begin{array}{l}\text { Powder }+1 \mathrm{~N} \\
\mathrm{KOH}\end{array}$ & Orange & $\begin{array}{l}\text { Blood } \\
\text { colour }\end{array}$ & Chestnut \\
\hline 13 & $\begin{array}{l}\text { Powder }+5 \\
\% \text { Iodine }\end{array}$ & Bay & $\begin{array}{l}\text { Dark } \\
\text { purple }\end{array}$ & $\begin{array}{l}\text { Dark } \\
\text { vinaceous }\end{array}$ \\
\hline 14 & $\begin{array}{l}\text { Powder }+5 \\
\% \mathrm{FeCl}_{3}\end{array}$ & Dull green & Sepia & $\begin{array}{l}\text { Brown } \\
\text { vinaceous }\end{array}$ \\
\hline 15 & $\begin{array}{l}\text { Powder }+ \\
\text { Liquid } \mathrm{NH}_{3}\end{array}$ & Isabelline & Hazal & Olivaceous \\
\hline
\end{tabular}


Shyam Baboo Prasad et.al., Pharmacognostic Evaluation of Syzygium Cumini (L.) Skeels Leaf

\begin{tabular}{|c|c|c|}
\hline \multicolumn{3}{|c|}{ Table 5 - Physico-chemical parameter } \\
\hline S.No & Parameter & Result \\
\hline 1 & Loss on drying & $5.26 \%$ \\
\hline 2 & Total Ash & Should not be more than $3.1 \%$ \\
\hline 3 & Acid insoluble ash & Should not be more than $0.7 \%$ \\
\hline 4 & $\begin{array}{l}\text { Water soluble } \\
\text { extractive }\end{array}$ & Should not be less than $12.32 \%$ \\
\hline 5 & $\begin{array}{l}\text { Alcohol soluble } \\
\text { extractive }\end{array}$ & Should not be less than $10.96 \%$ \\
\hline
\end{tabular}

Figure 1 :Leaves of Syzygium cumini (L.) SKEELS

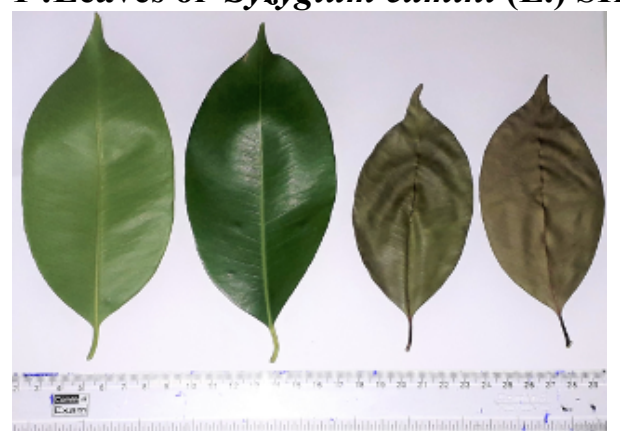

Transverse sections of Syzygium cumini (L.) Skeels

Figure 2a: TS of leaf( dorsiventral ) passing through midrib at $4 X$

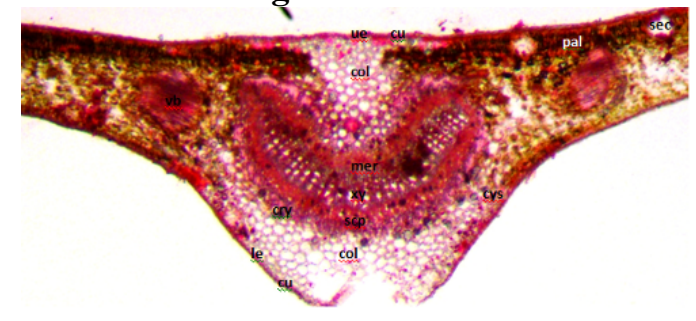

Upper epidermis (ue) covered with cuticle(cu), followed by single layered elongated palisade layer(pal) disrupted by secretory canal (sec) and spongy cells disrupted by vascular bundle(vb), centrally placed meristele (mer) i.e. forming an arc having lignified xylem( $x y)$ towards upper surface arranged in radiating bands spreading towards lower surface, protoxylem pointing towards upper surface and phloem bands at lower side, vascular bundle covered with sclerenchymatous pericycle bands( scp) and below to that endodermis, lower collenchymas shows deposition of crystal sheath (cry), starch grain (sg), cystolith (cys), below that lower epidermis (le) covered with cuticle(cu).

Figure 2b: TS of Leaf passing through midrib lower region at $10 \mathrm{X}$

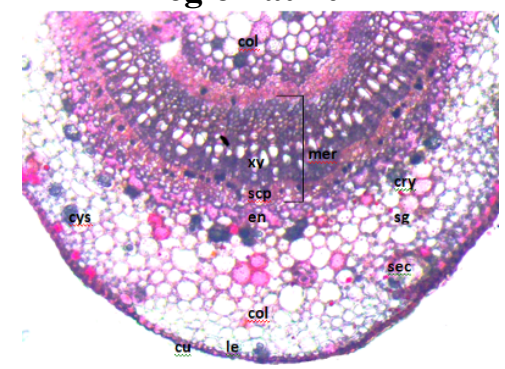

Upper collenchyma (col), centrally placed meristele (mer) i. e. forming an arc having lignified xylem (xy) towards upper surface arranged in radiating bands spreading towards lower surface, protoxylem pointing towards upper surface and phloem bands at lower side, vascular bundle covered with sclerenchymatous pericycle bands( scp) and below to that endodermis, lower collenchyma showing deposition of crystal sheath (cry), starch grain(sg), cystolith (cys) and secretory canal (sec), single layered lower epidermis (le) covered with cuticle (cu).

Figure 2c: TS of leaf (dorsiventrally) lamina at $10 \mathrm{X}$

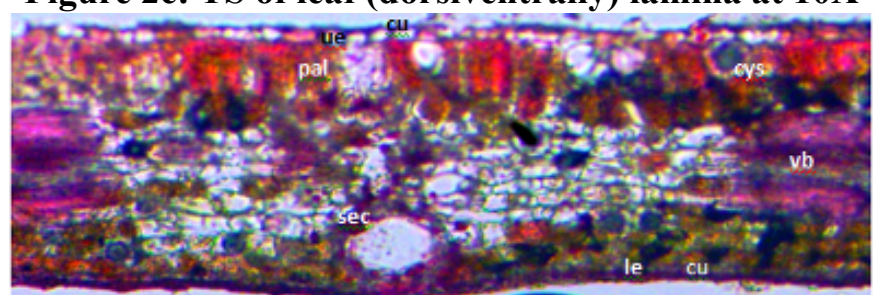

Showing upper epidermis(ue) covered with cuticle(cu), mesophyll divided into single layered palisade(pal) layer and 7-8 layered spongy cells disrupted by secretory ducts (sec) and vascular bundles, cystolith (cys) and starch grain (sg) seen, single layered lower epidermis (le) covered with cuticle (cu).

Figure : 3 Powder microscopy of Syzygium cumini (L.) SKEELS at 10X

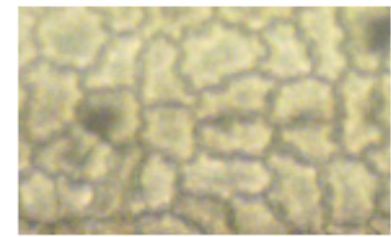

a

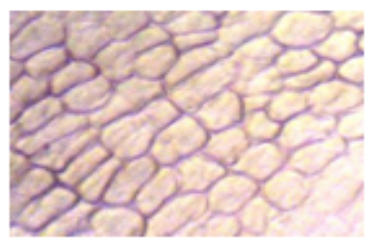

c

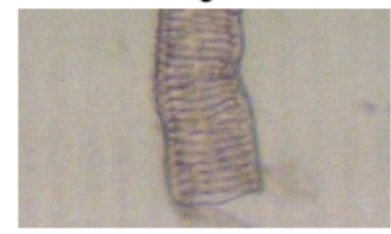

$\mathbf{e}$

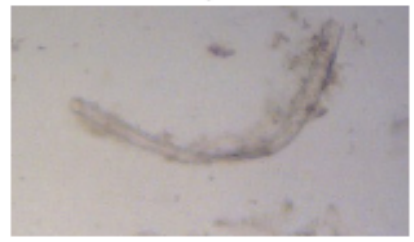

g

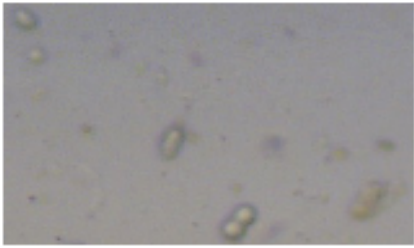

$\mathbf{i}$

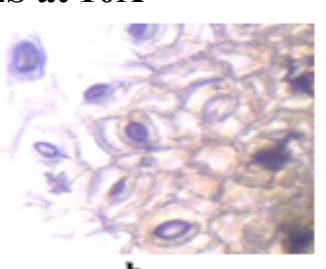

b
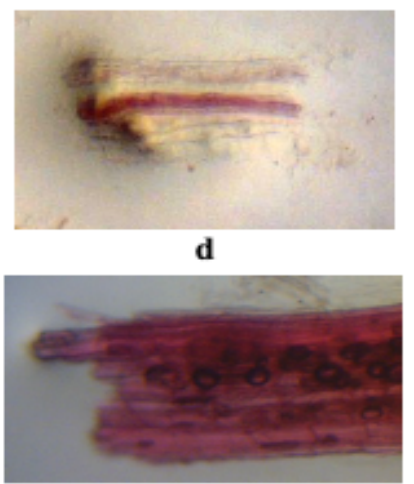

$\mathbf{f}$

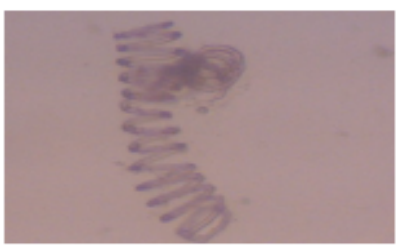

h

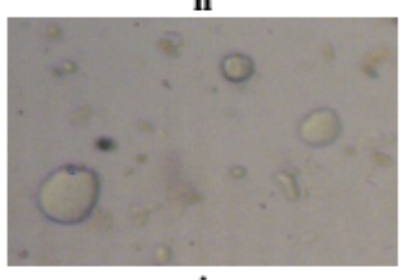


(a. Upper Epidermis (wavy epidermal cell in surface view), b. Lower epidermis with anisocytic stomata in surface view, c. Epidermis of Midrib (polygonal and non uniform) in surface view, d. Palisade cells with spherides and spongy cells in sectional view, e. pitted vessels, f. Calcium oxalate crystal sheath, g. Fragment of fibres and h. Spiral vessels, i. Simple and compound starch grain, J. Fixed oil).

\section{Acknowledgments}

Authors are highly thankful to The DirectorGeneral CCRAS, New Delhi for providing facilities, his constant support, and inspiration.

\section{References}

1. Plant Details for a Syzygium cumini (L.) SKEELS. h t tp://envis.frlht.org/plantdetails/ 899cfda0961c4089c22840744d082c34/9010e37aa6 $4246 \mathrm{a} 5 \mathrm{cb} 0091 \mathrm{e} 0774060 \mathrm{cb}$. dated 14/03/2019. time. 11.16 IST.

2. Anonymous, The Ayurvedic Pharmacopoeia of India Part- i Volume - ii, The Ayurvedic Pharmacopoeia Of India Part- I Volume - II Ministry of Health and Family Welfare Department of AYUSH, Government of India; 2016 57-60p

3. Bijauliya RK, Alok S, Singh M, Mishra SB. Morphology, phytochemistry and pharmacology of Syzygium cumini (Linn.)-an overview. International
Journal of Pharmaceutical Sciences and Research. 2017; Jun 1;8 (6) :2360-71.

4. Ramya S, Neethirajan K, Jayakumararaj R. Profile of bioactive compounds in Syzygium cumini-a review. J. Pharm. Res. 2012; Aug; 5(1) : 4548-53.

5. Verma, H., Prasad, S.B. and Yashwant, S.H.,. Herbal drug delivery system: A modern era prospective. Int J Current Pharma Rev Res 2013; 4, pp.88-101.

6. Singh NP, Karthikeyan S, Laxminarasimhan $\mathrm{P}$, Psasanna PV.. Flora of Maharashtra state Dicotyledones Vol.2, Calcutta-. Botanical survey of India; 2000. P10.

7. Anonymous. Quality Control Methods for Medicinal Plants Materials. Geneva: World Health organization; 1998

8. Khandelwal KR. Practical PharmacognosyTechniques and Experiments. Pune: Nirali Prakashan; 2003.

9. Kokate CK, Purohit AP, Gokhale SB. Text book of Pharmacognosy. Pune: Nirali Prakashan. 2003.

10. Anonymous. The Ayurvedic Pharmacopoeia of India Part 1 Volume 5. Ministry of Health and family welfare Goverment of India, Department of AYUSH; 2006. 2013-214p.

11. Chauhan MG, Pillai A.P.G. Microscopic profile of Powdered drugs used in Indian System of medicine Volume 2 - Leaf drugs, Surya Offset, Ahmedabad. 2011. 